\title{
PENDEKATAN PENDIDIKAN MATEMATIKA REALISTIK BERBASIS ETNOMATEMATIKA DAN PRESTASI BELAJAR SISWA
}

\author{
Irmina Veronika Uskono, Meryani Lakapu, Yohanes Ovaritus Jagom, Wilfridus \\ Beda Nuba Dosinaeng, Kornelis Bria \\ Universitas Katolik Widya Mandira, Kupang, Indonesia \\ Email: veniuskono@gmail.com
}

\begin{abstract}
Abstrak
Buna merupakan salah satu motif tenun dari Insana, Provinsi Nusa Tenggara Timur, Indonesia, yang menggunakan motif geometris seperti belah ketupat. Materi belah ketupat sulit dipahami siswa sehingga siswa hanya menghafal rumus tanpa memahami konsep. Guna mengatasinya, Buna digunakan sebagai media pembelajaran berbasis etnomatematika. Tujuan yang ingin dicapai dalam penelitian ini yaitu untuk mengetahui pengaruh penerapan pendekatan matematika realistik berbasis etnomatematika terhadap prestasi belajar matematika siswa. Penelitian ini merupakan penelitian kuantitatif dengan desain penelitian yaitu one-group pretest-posttest design. Populasi dalam penelitian ini yaitu seluruh siswa kelas V SDN Bestobe, Insana. Data yang digunakan yaitu data nilai pretest dan posttest. Uji statistik yang digunakan yaitu paired sample t-test. Hasil penelitian menunjukkan bahwa terdapat pengaruh yang signifikan dari penerapan pendekatan Pendidikan Matematika Realistik berbasis Etnomatematika terhadap prestasi belajar matematika siswa. Hasil ini berkontribusi dalam menambah bukti empiris terkait hubungan pendekatan Pendidikan Matematika Realistik berbasis Etnomatematika terhadap prestasi belajar siswa.
\end{abstract}

Kata Kunci: tenun buna, etnomatematika, prestasi belajar, pendidikan matematika realistik

\begin{abstract}
Buna is one of the woven motifs from Insana, East Nusa Tenggara Province that uses geometric motifs like a rhombus. Rhombus is a challenging material so students only memorize the formula without understanding the concept. In order to overcome this problem, a weaving learning based on ethnomathematics has been proposed. The purpose of this study is to understand the impact on the learning achievement of students of the implementation of a realistic mathematical approach based on ethnomathematics. This is a quantitative study using a one-group pretest-posttest design. The population for this study is all fifth-grade students of SDN Bestobe, Insana District. Pretest and posttest results obtained are used for the analysis. The statistical test used is a paired sample t-test. The results show that the implementation of realistic mathematical learning based on ethnomathematics has a substantial influence on the learning achievement of mathematics students. These results contribute to adding empirical evidence related to the relationship between Ethnomathematics-based Realistic Mathematics Education approaches to student achievement.
\end{abstract}

Keywords: tenun buna, ethomathematics, learning achievement, realistic mathematics education

\section{PENDAHULUAN}

Matematika merupakan salah satu mata pelajaran yang mempunyai peranan penting dalam kehidupan sehari-hari, karena dapat melatih siswa bepikir logis, kritis dan 
sistematis. Menurut Hans Freudenthal dalam Hadi (2015), matematika merupakan aktivitas insani, sehingga siswa tidak dapat dipandang sebagai penerima pasif matematika yang sudah jadi. Oleh karena itu pelajaran matematika diberikan kepada siswa harus dapat mengembangkan kemampuan berpikir siswa, mulai dari tingkat sekolah dasar hingga sekolah menengah atas. Mengingat pentingnya peranan matematika tersebut, maka salah satu hal yang menjadi perhatian guru yaitu prestasi belajar matematika siswa.

Prestasi belajar matematika merupakan tingkat penguasaan siswa terhadap materi yang telah diperoleh dari hasil tes belajar yang dinyatakan dalam bentuk skor (Poro, Rowa, \& Uskono, 2017). Pendapat lain tentang prestasi belajar matematika juga dikemukakan oleh Jagom \& Uskono (2019), yang menyatakan bahwa prestasi belajar matematika merupakan penguasaan pengetahuan dan keterampilan yang dikembangkan dalam bidang studi matematika yang diperoleh melalui proses usaha siswa dalam interaksi aktif subjek dengan lingkungannya yang dapat dilihat dari hasil belajar matematika siswa. Dengan demikian, prestasi belajar matematika yang dimaksud dalam penelitian ini yaitu tingkat penguasaan pengetahuan siswa terhadap materi melalui proses interaksi dengan lingkungan yang dinyatakan dalam bentuk skor. Salah satu alternatif yang diterapkan untuk meningkatkan prestasi belajar matematika siswa yaitu melalui pendekatan pendidikan matematika realistik.

Dalam filsafat pendidikan matematika realistik, siswa harus diberi kesempatan untuk menemukan kembali matematika di bawah bimbingan orang dewasa, dan penemuan kembali ide dan konsep matematika tersebut harus dikembangkan mulai dari berbagai persoalan dunia nyata (Hadi, 2005). Pendapat lain dikemukakan oleh (Soedjadi, 2001) yaitu bahwa pembelajaran matematika realistik pada dasarnya adalah pemanfaatan realitas dan lingkungan yang dipahami peserta didik untuk memperlancar proses pembelajaran matematika sehingga dapat mencapai tujuan pendidikan matematika secara lebih baik daripada masa yang lalu. Menurut Uskono, Djong, \& Leton (2019), pembelajaran matematika realistik merupakan pembelajaran yang menitikberatkan pada pemberian masalah yang dekat dengan kehidupan sehari-hari siswa. Dunia nyata dalam pendidikan matematika realistik digunakan sebagai titik awal untuk pengembangan ide dan konsep matematika, sehingga siswa siswa dapat terlibat dalam proses pembelajaran secara bermakna, di bawah bimbingan guru. Hal ini juga senada dengan pernyataan Mumu \& Aninam (2018) bahwa pembelajaran matematika hendaknya dimulai dengan 
permasalahan kontekstual yang siswa alami setiap hari, atau paling tidak dimulai dari sesuatu hal yang dapat dibayangkan dan dirasakan. Pendekatan pembelajaran matematika ini dikenal dengan Etnomatematika.

Etnomatematika merupakan suatu pendekatan yang dapat dipergunakan untuk menjelaskan realitas hubungan antara budaya lingkungan dan matematika sebagai rumpun ilmu. Pembelajaran matematika berbasis budaya merupakan suatu pendekatan yang diharapkan mampu menjadi alternatif dalam melakukan inovasi pembelajaran, yang pengembangannya dilakukan sesuai dengan kearifan lokal sekolah setempat sehingga diharapkan mampu meningkatkan hasil belajar siswa (Astutiningtyas, Wulandari, \& Farahsanti, 2017). Mengntegrasikan budaya sebagai konteks dalam pembelajaran matematika dapat membentuk karakter siswa yang mencintai budaya, sehingga mereka dapat mengaplikasikannya dalam kehidupan sehari-hari (Mumu \& Aninam, 2018).

Penelitian terkait etnomatematika dilakukan oleh (Massarwe, Verner, \& Bshouty, 2012), (Rosa \& Orey, 2011), (Supiyati, Hanum, \& Jailani, 2019). Penelitian terkait ethnomatematika dan pendekatan matematika realistik dilakukan oleh (Nursyahidah, Saputro, \& Rubowo, 2018), (Peni, 2019). Penelitian terkait hubungan motif tenun dan pembelajaran matematika dilakukan oleh (Deda \& Disnawati, 2017). Dengan demikian, pembelajaran matematika dengan pendekatan etnomatematika dapat dijadikan salah satu media pembelajaran matematika untuk meningkatkan prestasi belajar siswa dan juga memperkenalkan budaya.

Tenun buna merupakan salah satu tenunan asli masyarakat adat suku-suku di sonaf maubes (Kerajaan Maubesi), Kecamatan Insana Kabupaten Timor Tengah Utara Propinsi Nusa Tenggara Timur (Tas'au, 2016) Motif yang digunakan pada tenun buna yaitu motif geometris, dimana setiap motif merupakan perwakilan suku-suku yang mendiami wilayah kerajaan dalam tatanan struktur adat masyarakat sonaf maubes (Tas'au, 2016).

Secara umum, kain tenun digunakan oleh masyarakat Nusa Tenggara Timur untuk upacara adat masuk minta/peminangan, belis (mas kawin), pernikahan, menghormati leluhur, menerima/menyambut tamu (natoni), pemakaman, untuk membedakan derajat atau strata sosial dalam masyarakat, sebagai alat tukar, serta untuk pakaian kerja harian (Mamulak, 2015). Dengan demikian, tentunya siswa-siswi sekolah dasar di Kecamatan Insana Barat tidak asing dengan motif tenun buna, karena merupakan warisan budaya 
leluhur yang turun temurun selalu digunakan dalam kehidupan sehari-hari. Contoh motif tenun buna dapat dilihat pada Gambar 1.
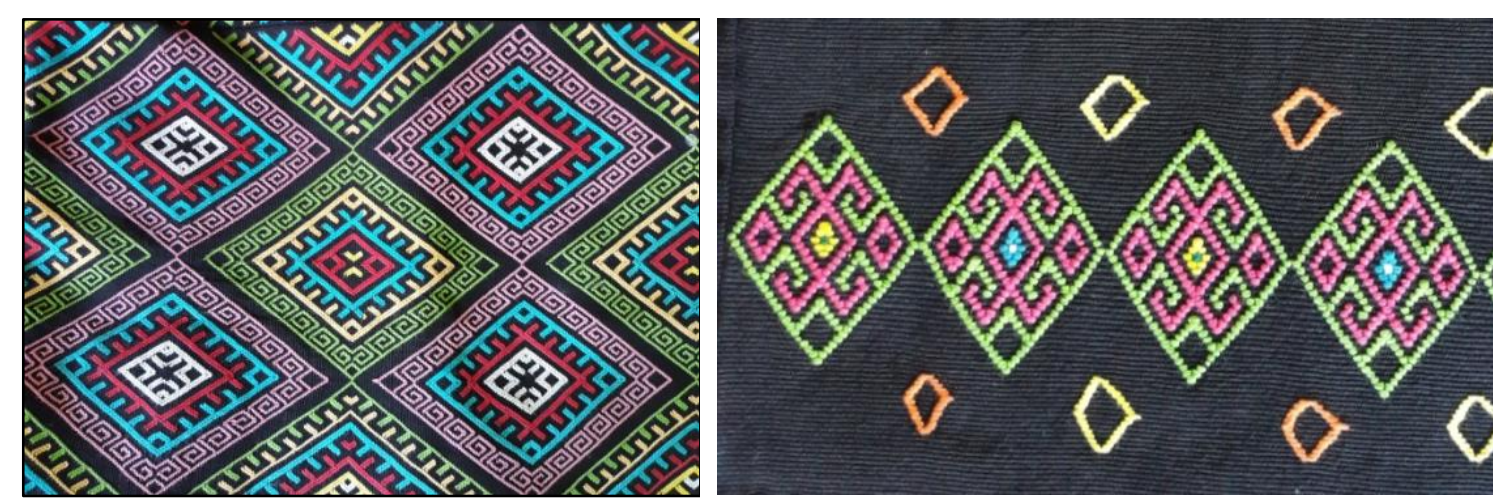

Sumber: Dokumentasi Peneliti, 2019

Gambar 1. Contoh motif tenun Buna

Berdasarkan dari hasil wawancara dengan guru di salah satu sekolah negeri di Kecamatan Insana Barat, Kabupaten Timor Tengah Utara, ditemukan bahwa siswa kurang memahami konsep luas dan keliling belah ketupat dengan baik dan benar. Siswa hanya menghafal rumus luas belah ketupat tanpa tahu konsep dari luas tersebut. Selain itu, untuk memahami konsep belah ketupat, pembelajaran sebaiknya dapat dilakukan dengan menggunakan media pembelajaran. Salah satu alternatif yang digunakan yaitu, pembelajaran matematika pada materi bangun datar belah ketupat menggunakan media tenun buna.

Dalam penelitian ini, peneliti menerapkan pembelajaran matematika realistik dengan menggunakan tenun buna sebagai media pembelajaran yang dekat dengan kehidupan sehari-hari siswa. Dengan menggunakan media pembelajaran berupa tenun buna, siswa diharapkan dapat memiliki pemahaman tentang konsep bangun datar belah ketupat dengan tepat, sehingga dapat meningkatkan prestasi belajar matematika siswa sekolah dasar. Dengan demikian, tujuan yang ingin dicapai dalam penelitian ini yaitu untuk mengetahui pengaruh pembelajaran matematika realistik berbasis etnomatematika terhadap prestasi belajar matematika siswa sekolah dasar.

\section{METODE PENELITIAN}

Jenis penelitian yang digunakan yaitu penelitian kuantitatif komparatif dengan metode quasi ekaperimen. Desain penelitian yang digunakan yaitu one-group pretestposttest design. Data dalam penelitian ini yaitu nilai pretest dan posttest. Populasi dalam 
penelitian ini yaitu seluruh siswa kelas V SDN Bestobe Kabupaten Timor Tengah Utara tahun pelajaran 2019/2020 yang berjumlah 8 orang siswa, sehingga teknik pengambilan sampel yang digunakan yaitu sampling jenuh. Materi yang dipelajari dalam penelitian ini yaitu bangun datar belah betupat.

Penelitian dilaksanakan dengan prosedur sebagai berikut:

1) Menyiapkan perangkat pembelajaran yang terdiri dari recana pelaksanaan pembelajaran (RPP), bahan ajar, lembar kerja siswa (LKS) dapat dilihat pada Gambar 2, tes hasil belajar (THB) dan selendang dengan motif tenun buna yang digunakan sebagai media pembelajaran berbasis etnomatematika.

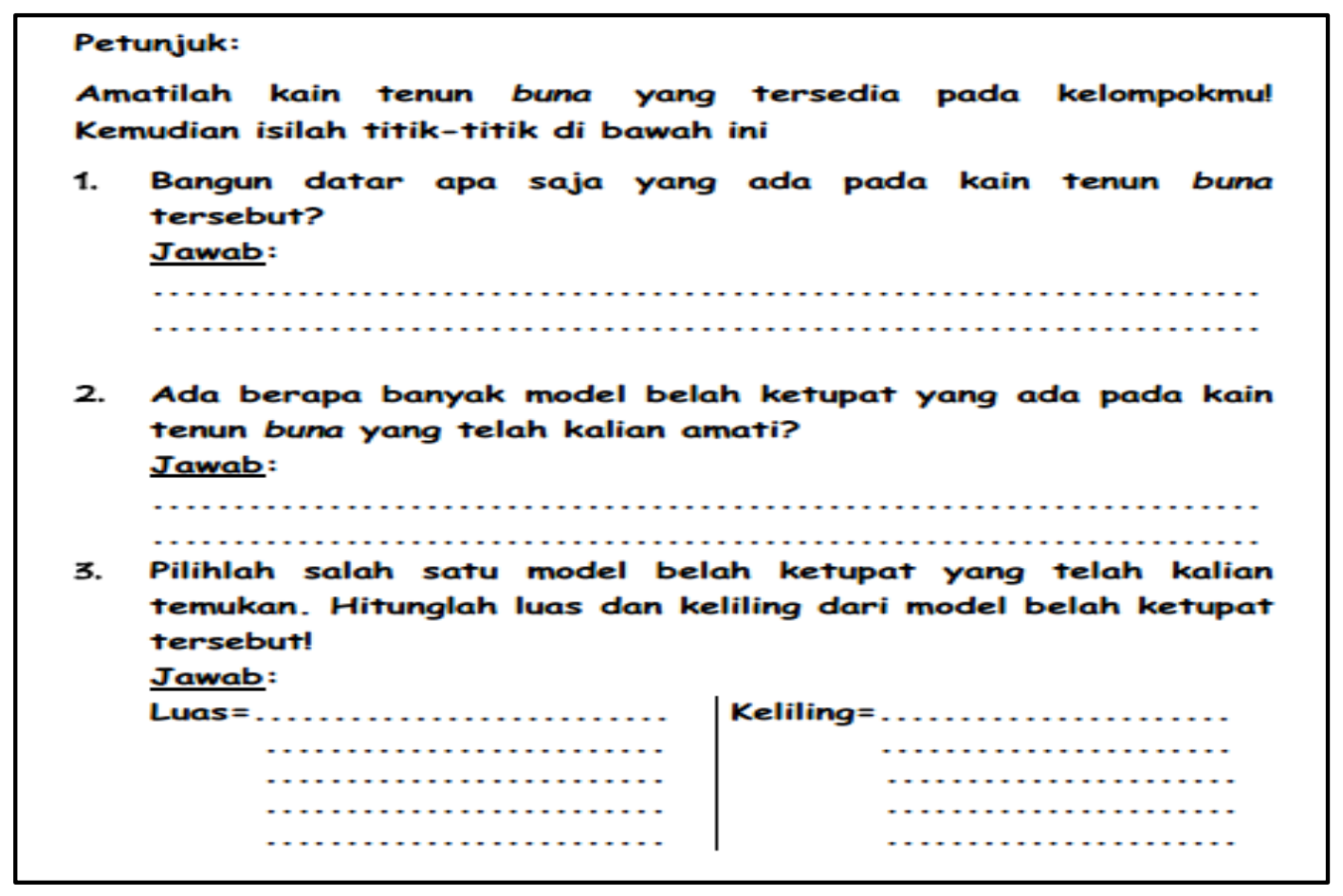

Gambar 2. Lembar kerja siswa

2) Melaksanakan pre-test.

3) Menerapkan pembelajaran matematika realistik berbasis etnomatematika pada siswa kelas $\mathrm{V}$ dengan menggunakan media pembelajaran berupa selendang tenun buna.

4) Melaksanakan post-test.

5) Analisis data berupa uji Normalitas dan uji Hipotesis. Uji normalitas data menggunakan One Sample Kolmogorov-Smirnov Test, sedangkan uji hipotesis menggunakan Paired Sample T-Test. Pengujian dilakukan dengan menggunakan paket program SPSS (Statistical Package for Social Science). 
Hipotesis yang digunakan pada uji normalitas dalam penelitian ini sebagaimana dikemukanan (Gunawan, 2013), yaitu:

$H_{0}$ : data berdistribusi normal

$H_{1}$ : data tidak berdistribusi normal

Pada taraf signifikansi 5\%, kriteria pengujian yang digunakan pada uji normalitas yaitu jika nilai $D_{\text {hitung }}$ lebih kecil dari nilai $D_{\text {tabel }}$ dan nilai signifikansinya lebih besar dari 0,05 maka $H_{0}$ diterima, sehingga dapat dikatakan bahwa data berdistribusi normal. Sebaliknya jika nilai $D_{\text {hitung }}$ lebih besar dari nilai $D_{\text {tabel }}$ dan nilai signifikansinya lebih kecil dari 0,05 maka $H_{0}$ ditolak, sehingga dapat dikatakan bahwa data tidak berdistribusi normal.

Hipotesis yang digunakan untuk menguji pengaruh perlakuan adalah Paired Sample t-test yaitu:

$H_{0}$ : tidak ada pengaruh penerapan pembelajaran matematika realistik berbasis etnomatematika terhadap prestasi belajar matematika siswa SD

$H_{1}$ : ada pengaruh penerapan pembelajaran matematika realistik berbasis etnomatematika terhadap prestasi belajar matematika siswa SD

Kriteria pengujian yang digunakan yaitu jika nilai $-t_{\text {tabel }} \leq t_{\text {hitung }} \leq t_{\text {tabel }}$ atau nilai signifikansinya lebih besar dari 0,05 maka $H_{0}$ tidak dapat ditolak. Dengan demikian dapat disimpulkan bahwa tidak ada pengaruh penerapan pembelajaran matematika realistik berbasis etnomatematika terhadap prestasi belajar matematika siswa SD. Sebaliknya, jika nilai $t_{\text {hitung }}>t_{\text {tabel }}$ atau $t_{\text {hitung }}<-t_{\text {tabel }}$ atau nilai signifikansinya lebih kecil dari 0,05 maka $H_{0}$ ditolak. Dengan demikian dapat disimpulkan bahwa ada pengaruh penerapan pembelajaran matematika realistik berbasis etnomatematika terhadap prestasi belajar matematika siswa SD.

\section{HASIL DAN PEMBAHASAN}

\section{Tenun Buna sebagai Media Pembelajaran}

Penerapan pembelajaran matematika realistik di salah satu sekolah dasar negeri di kecamatan Insana Barat berjalan dengan baik dan lancar. Siswa mempelajari materi belah ketupat dengan menggunakan media pembelajaran selendang tenun buna. Tenun buna 
bagi masyarakat Insana merupakan warisan leluhur yang digunakan sehari-hari. Hal ini sesuai dengan pernyataan (Mumu \& Aninam, 2018) bahwa mengintegrasikan budaya sebagai konteks dalam pembelajaran matematika dapat membentuk karakter siswa yang mencintai budaya mengaplikasikannya dalam kehidupan sehari-hari. Lebih lanjut, (Mumu \& Aninam, 2018) menyatakan bahwa pembelajaran matematika dimulai dengan permasalahan kontekstual yang siswa alami setiap hari, atau paling tidak dimulai dari sesuatu hal yang dapat dibayangkan dan dirasakan.

Pada pelaksanaan pembelajaran, siswa dikelompokkan menjadi empat kelompok dengan masing-masing kelompok terdiri dari dua orang siswa. Siswa pada masingmasing kelompok mengerjakan lembar kerja siswa yang diberikan dengan mengamati selendang tenun buna yang ada pada masing-masing kelompok. Pada lembar kerja siswa, mula-mula siswa mengamati selendang tenun buna yang ada. Setelah itu siswa menentukan jenis-jenis bangun datar yang ada pada selendang tenun buna. Selanjutnya siswa menghitung banyaknya model belah ketupat yang diamati. Langkah terakhir yaitu siswa memilih salah satu model belah ketupat untuk dihitung luas dan kelilingnya.

Pelaksanaan pembelajaran matematika realistik menggunakan media tenun Buna dapat dilihat pada Gambar 3. Gambar 3(a) menunjukkan bahwa siswa sekolah dasar sedang memilih model belah ketupat yang ada pada selendang tenun Buna untuk dipelajari. Gambar 3(b) menunjukkan bahwa siswa sedang mengukur diagonal dari belah ketupat pada selendang tenun buna. Dapat dilihat juga bahwa siswa aktif dalam pembelajaran ini, dimana siswa berdiskusi dalam kelompok kecil.

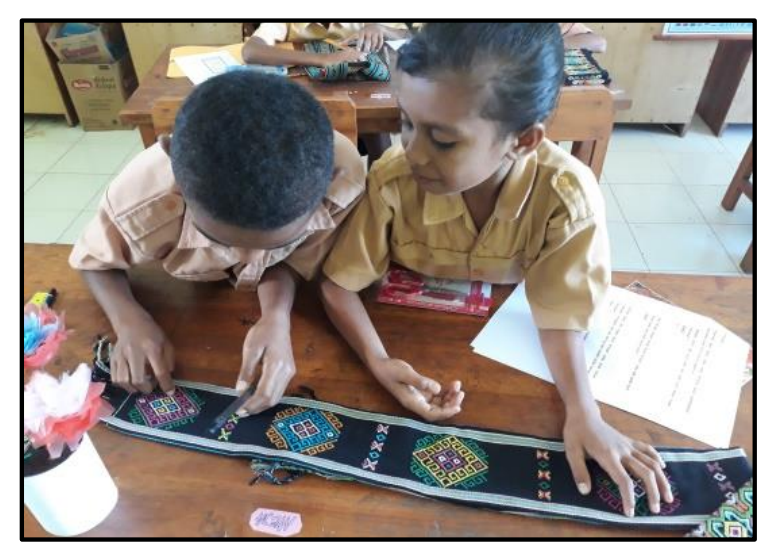

(a)

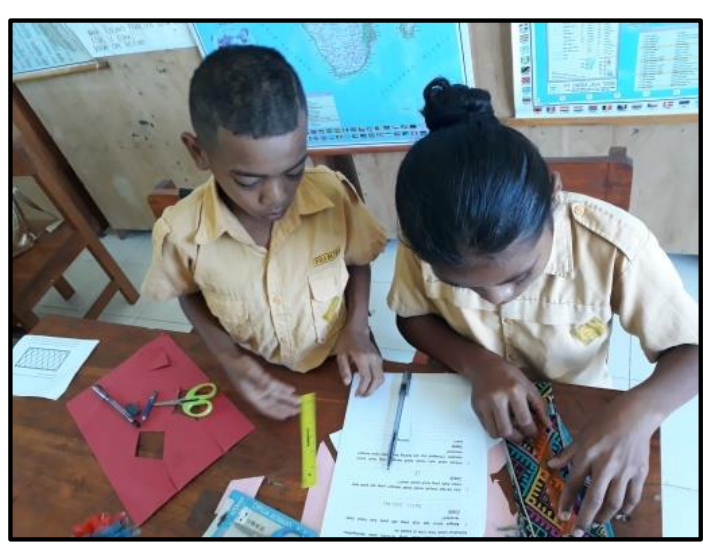

(b)

Gambar 3. Pelaksanan pembelajaran menggunakan selendang tenun buna 
Tenun Buna yang digunakan dalam pembelajaran ini merupakan salah satu inovasi yang digunakan untuk memahami materi belah ketupat pada siswa sekolah dasar yang berasal dari kehidupan sehari-hari siswa. Penelitian ini mengambil peran sebagai tambahan referensi tentang penerapan etnomatematika dalam pembelajaran matematika secara khusus untum mempelajari materi belah ketupat. Hal ini sesuai dengan pernyataan (Astutiningtyas, Wulandari, \& Farahsanti, 2017) yang menyatakan bahwa pembelajaran matematika berbasis budaya merupakan suatu pendekatan yang diharapkan mampu menjadi alternatif dalam melakukan inovasi pembelajaran, yang pengembangannya dilakukan sesuai dengan kearifan lokal sekolah setempat sehingga diharapkan mampu meningkatkan hasil belajar siswa.

Peningkatan prestasi belajar siswa dapat dilihat dari rata-rata nilai pretest dan posttest, yaitu rata-rata nilai posttest yang lebih tinggi dari rata-rata nilai pretest. Hasil analisis secara statistik berdasarkan perolehan nilai siswa tersebut menunjukkan bahwa penerapan pembelajaran matematika realistik berbasis etnomatematika mempunyai pengaruh yang signifikan terhadap prestasi belajar siswa.

\section{Hasil Uji Normalitas Data}

Hasil output SPSS uji normalitas menggunakan One-Sample Kolmogorov-Smirnov test pada data nilai pretest dan posttest dapat dilihat pada Tabel 1.

Tabel 1. One-Sample Kolmogorov-Smirnov Test

\begin{tabular}{|ll|r|r|}
\hline & & Pretest & Posttest \\
\hline $\mathrm{N}$ & & 8 & 8 \\
Normal Parameters ${ }^{\mathrm{a}, \mathrm{b}}$ & Mean & 51,00 & 68,38 \\
& Std. Deviation & 3,703 & 10,364 \\
\multirow{2}{*}{ Most Extreme Differences } & Absolute &, 235 &, 225 \\
& Positive &, 231 &, 165 \\
& Negative &,- 235 &,- 225 \\
& &, 235 &, 225 \\
Test Statistic & &, $200^{\mathrm{c}, \mathrm{d}}$ &, $200^{\mathrm{c}, \mathrm{d}}$ \\
Asymp. Sig. (2-tailed) & & &
\end{tabular}

Pada hasil output SPSS dari data pretest diperoleh nilai $D_{\text {hitung }}=0,235$ dan nilai Sig $=0,200$. Nilai $D_{\text {tabel }}$ yang diperoleh yaitu 0,454 . Hal ini menunjukkan bahwa nilai $D_{\text {hitung }}=0,235<0,454=D_{\text {tabel }}$ dan nilai Sig $=0,200>0,05=\alpha$. Berdasarkan kriteria 
pengujian pada uji normalitas, dapat simpulkan bahwa $H_{0}$ diterima yang berarti data nilai pretest berdistribusi normal. Pada hasil output SPSS dari data posttest diperoleh nilai $D_{\text {hitung }}=$ 0,225 dan nilai $\operatorname{Sig}=0,200$. Nilai $D_{\text {tabel }}$ yang diperoleh yaitu 0,454 . Hal ini menunjukkan bahwa nilai $D_{\text {hitung }}=0,225<0,454=D_{\text {tabel }}$ dan nilai Sig $=0,200>0.05=\alpha$. Berdasarkan kriteria pengujian pada uji normalitas, dapat simpulkan bahwa $H_{0}$ diterima yang berarti data nilai posttest berdistribusi normal.

\section{Hasil Uji Hipotesis Penelitian}

Data nilai pretest dan posttest berdistribusi normal, maka selanjutnya dilakukan uji hipotesis menggunakan Paired Sample T- Test. Hasil output SPSS uji hipotesis menggunakan Paired Sample T- Test dapat dilihat pada Tabel 2.

Tabel 2. Paired Sample T-Test

\begin{tabular}{|c|c|c|c|c|c|c|c|c|}
\hline & \multicolumn{5}{|c|}{ Paired Differences } & \multirow[b]{3}{*}{$\mathrm{t}$} & \multirow[b]{3}{*}{ df } & \multirow{3}{*}{$\begin{array}{l}\text { Sig. }(2- \\
\text { tailed) }\end{array}$} \\
\hline & \multirow{2}{*}{ Mean } & \multirow{2}{*}{$\begin{array}{c}\text { Std. } \\
\text { Deviation }\end{array}$} & \multirow{2}{*}{$\begin{array}{l}\text { Std. Error } \\
\text { Mean }\end{array}$} & \multicolumn{2}{|c|}{$\begin{array}{c}95 \% \text { Confidence Interval } \\
\text { of the Difference }\end{array}$} & & & \\
\hline & & & & Lower & Upper & & & \\
\hline $\begin{array}{cl}\text { Pair } 1 \text { Posttest - } & \\
& \text { Pretest }\end{array}$ & 17,375 & 10,099 & 3,570 & 8,932 & 25,818 & 4,866 & 7 & ,002 \\
\hline
\end{tabular}

Pada hasil output SPSS (Tabel 2), diperoleh bahwa nilai $t_{\text {hitung }}=4,866$ dan nilai Sig $=0,002$. Nilai $t_{\text {tabel }}$ yang diperoleh yaitu 2,365 , menunjukkan bahwa nilai $t_{\text {hitung }}=$ $4,866>2,365=t_{\text {tabel }}$ dan nilai Sig $=0,002<0.05=\alpha$. Berdasarkan kriteria pengujian pada uji hipotesis, dapat simpulkan bahwa $H_{0}$ ditolak yang berarti ada pengaruh penerapan pembelajaran matematika realistik berbasis etnomatematika terhadap prestasi belajar matematika siswa SD. Berdasarkan data nilai diperoleh keterangan bahwa rata-rata nilai posttest lebih tinggi dari rata-rata pretest.

Hasil penelitian menunjukkan bahwa tenun Bona, sebagai hasil budaya Masyarakat suku-suku di sonaf maubes Nusa Tenggara Timur, dapat digunakan sebagai media pembelajaran matematika. Hal ini sesuai dengan pendapat Risdiyanti \& Prahmana (2020), yang menyatakan bahwa etnomatematika mempunyai peranan penting dalam meningkatkan pemahaman siswa. Etnomatematika jika diterapkan dalam pembelajaran matematika, maka proses pembelajaran matematika akan dilakukan dengan cara siswa 
melakukan eksplorasi ide-ide matematika, cara, praktik, atau penyelesaian masalah yang dikembangkan oleh anggota suatu budaya tertentu.

\section{KESIMPULAN}

Penerapan pembelajaran matematika realistik berbasis etnomatematika, dengan menggunakan tenun Buna, mempunyai pengaruh yang signifikan terhadap prestasi belajar matematika siswa kelas V sekolah dasar negeri di Kabupaten Timor Tengah Utara. Penggunaan media pembelajaran berupa tenun buna dapat dijadikan salah satu alternatif dalam merancang kegiatan pembelajaran di kelas, karena dapat meningkatkan prestasi belajar matematika siswa.

\section{DAFTAR RUJUKAN}

Astutiningtyas, E. L., Wulandari, A. A., \& Farahsanti, I. (2017). Etnomatematika Dan Pemecahan Masalah Kombinatorik. Jurnal Math Educator Nusantara (JMEN), 3(2), 111-118.

Deda, Y. N., \& Disnawati, H. (2017). Hubungan Motif Kain Tenun Masyarakat Suku Dawan - Timor Dengan Matematika Sekolah. Konferensi Nasional Penelitian Matematika dan Pembelajarannya (KNPMP II) (hal. 201-209). Surakarta: Universitas Muhammadyah Surakarta.

Gunawan, M. A. (2013). Statistik Untuk Penelitian Pendidikan. Yogyakarta: Parama Publishing.

Hadi, S. (2005). Pendidikan Matematika Realistik dan Implementasinya. Banjarmasin: Tulip.

Jagom, Y. O., \& Uskono, I. V. (2019). Pengaruh Penggunaan Alat Peraga Berbahan Bekas Terhadap Hasil Belajar Matematika Siswa SMP. Math Didactic: Jurnal Pendidikan Matematika, 5(3), 219-2226.

Mamulak, N. M. (2015). Rancang Bangun Sistem Informasi Motif-Motif Tenunan Daerah Nusa Tenggara Timur Menggunakan Pendekatan Unified Process. Seminar Nasional Teknologi Informasi dan Komunikasi (SENTIKA) (hal. 399-405). Yogyakarta: Universitas Atma Jaya.

Massarwe, K., Verner, I., \& Bshouty, D. (2012). Ethnomathematics and Multi-Cultural Education: Analysis and Construction of Geometric Ornaments. Journal of Mathematics and Culture, 6(1), 344-367.

Mumu, J., \& Aninam, P. A. (2018). Analisis Konteks Asal Budaya Papua Dalam Pendidikan Matematika Realistik. Journal of Honai Math, 1(1), 24-33. 
Nursyahidah, F., Saputro, B. A., \& Rubowo, M. R. (2018). Students Problem Solving Ability Based on Realistic Mathematics with Ethnomathematics. JRAMathEdu : Journal of Research and Advances in Mathematics Education, 8(1), 13-24.

Peni, N. R. (2019). Development Framework of Ethnomathematics Curriculum through Realistic Mathematics Education Approach. IOSR Journal of Research \& Method in Education (IOSR-JRME), 16-24.

Poro, W. H., Rowa, Y. R., \& Uskono, I. V. (2017). Pengaruh Media Pembelajaran Matematika Terhadap Prestasi Belajar Matematika Siswa Pokok Bahasan Peluang. Prosiding Seminar Ilmiah Pendidikan STKIP Soe (hal. 64 - 70). Soe: LP3M STKIP Soe.

Risdiyanti, I., \& Prahmana, R. C. I. (2020). Etnomathematics (Teori dan Implementasi: Suatu Pengantar). Yogyakarta: UAD Press

Rosa, M., \& Orey, D. C. (2011). Ethnomathematics: The Cultural Aspects of Mathematics. Revista Latinoamericana de Etnomatematica, 4(2), 32-54.

Soedjadi, R. (2001). Pemanfaatan Realitas dan Lingkungan Dalam Pembelajaran Matematika. Seminar Nasional Realistic Mathematics Education (RME) (hal. 16). Surabaya: Jurusan Matematika FMIPA UNESA.

Supiyati, S., Hanum, F., \& Jailani. (2019). Ethnomathematics In Sasaknese Architecture. Journal on Mathematics Education, 10(1), 47-58.

Tas'au, P. R. (2016). Pelestarian Budaya Tenun Buna Dalam Mengembangkan Ekonomi Kerakyatan (Studi Etnografi Masyarakat Adat Sonaf Maubes). National Conference On Economic Education (hal. 1225-1240). Malang: Pascasarjana Universitas Negeri Malang.

Uskono, I. V., Djong, K. D., \& Leton, S. I. (2019). Penerapan Model Pembelajaran Matematika Realistik Pada Pokok Bahasan Bilangan Bulat. Range: Jurnal Pendidikan Matematika, 1(2), 138-144. 
Journal of Honai Math, Vol. 3, No. 2, pp. 145-156, Oktober 2020

Uskono, Lakapu, Jagom, Dosinaeng, \& Bria, Pendekatan Pendidikan Matematika Realistik Berbasis Etnomatematika dan Prestasi Belajar Siswa 